\title{
Perancangan Pengatur Nada Rendah dan Nada Tinggi Berbasis Komponen Pasif
}

\author{
Budihardja Murtianta \\ Program Studi Teknik Elektro, \\ Fakultas Teknik Elektronika dan Komputer, \\ Universitas Kristen Satya Wacana, Salatiga \\ budihardja.murtianta@uksw.edu
}

\begin{abstract}
Abstrak
Pada penelitian ini dirancang pengatur nada rendah dan nada tinggi berdasarkan teori-teori dan perhitungan-perhitungan elektronika. Untai pengatur nada rendah dan nada tinggi ini hanya menggunakan komponen elektronika pasif yaitu komponen yang tidak memerlukan catu daya dan tidak mempunyai penguatan daya. Pengatur nada rendah dapat mengatur penguatan dan pelemahan frekuensi rendah. Pengatur nada tinggi dapat mengatur penguatan dan pelemahan frekuensi tinggi. Pemisahan antara nada rendah dan nada tinggi pada titik frekuensi pusat $1 \mathrm{kHz}$. Penguatan dan pelemahan pengatur nada rendah dan nada tinggi masing-masing adalah $\pm 20 \mathrm{~dB}$. Untai ini menggunakan prinsip tapis pelewat frekuensi rendah dan tapis pelewat frekuensi tinggi orde 1. Hasil perancangan diukur dengan menggunakan Circuit Maker. Hasil simulasi menunjukkan pemisahan antara pengatur nada rendah dan nada tinggi menyimpang $2,7 \%$ dari $1 \mathrm{kHz}$ dan pengaturan nada rendah $+18,9 \mathrm{~dB}$ hingga $-16 \mathrm{~dB}$ serta pengaturan nada tinggi $+17,4 \mathrm{~dB}$ hingga $-12,7 \mathrm{~dB}$.
\end{abstract}

Kata kunci: frekuensi pusat, orde 1, nada rendah, nada tinggi

\begin{abstract}
In this study, the low and high tone control was designed based on electronic theories and calculations. The low and high tone control circuit uses only passive electronic components, that is, the components do not require a power supply and have no power gain. The low tone control can adjust the gain and attenuation of low frequencies. The high-tone control can adjust the gain and attenuation of high frequencies. The separation between low and high tone at a center frequency of $1 \mathrm{kHz}$. The gain and attenuation of the low and high tone control are $\pm 20 \mathrm{~dB}$ respectively. This circuits use the principle of a first-order low-pass filter and a first-order high-pass filter. The design results are measured using a Circuit Maker. The simulation results show that the separation between the low and high tone control deviates $2.7 \%$ from $1 \mathrm{kHz}$ and the low tone control range is $+18.9 \mathrm{~dB}$ to $-16 \mathrm{~dB}$ and the high tone control range is $+17.4 \mathrm{~dB}$ to $-12.7 \mathrm{~dB}$.
\end{abstract}

Keywords: center frequency, first-order, low tone, high tone

\section{Pendahuluan}

Pengaturan nada rendah (bass) dan nada tinggi (treble) yang saling bebas pada amplifier audio hifi (high fidelity) biasanya dilakukan dengan menggunakan rangkaian 
pengatur nada yang dirancang khusus. Jenis pengatur nada ini adalah pasif karena hanya menggunakan komponen pasif. Komponen elektronika pasif adalah jenis komponen elektronika yang tidak memerlukan sumber arus listrik eksternal untuk pengoperasiannya [1]. Pengatur nada ini mengacu pada rangkaian pengatur nada pasif Baxandall yang ditunjukkan pada Gambar 1 [2]. Pengaturan nada rendah dan nada tinggi dapat ditambah atau dipotong sebesar $20 \mathrm{~dB}$. Pada prinsipnya perancangan pengatur nada adalah menggunakan teori tapis dan perhitungan-perhitungan untuk menentukan nilai komponen-komponen serta titik-titik frekuensi penggal tapis.

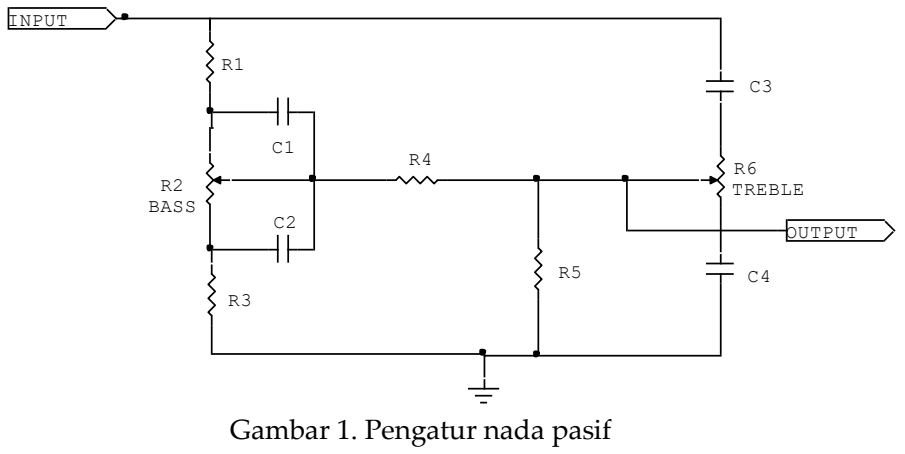

Pada penelitian ini dirancang rangkaian pengatur nada pasif Baxandall serta diadakan pengukuran dari hasil rancangannya. Rangkaian Baxandall memiliki dua kapasitor pada tiap potensiometernya, tetapi dimungkinkan untuk menggunakan hanya satu pada potensiometer nada rendah atau nada tinggi, atau keduanya [3]. Rangkaian Baxandall diaplikasikan dalam peralatan audio $h i-f i$ dan pada penguat (amplifier) serta efek untuk alat musik [4].

\section{Metode Penelitian}

Sebagaian besar sistem komunikasi menggunakan tapis-tapis. Tapis akan melewatkan pita frekuensi tertentu yang diinginkan dan menolak pita frekuensi lain yang tidak diinginkan. Tapis dapat berupa tapis pasif atau aktif. Tapis pasif terdiri dari komponen-komponen pasif seperti resistor, kapasitor dan induktor. Tapis pasif tidak mempunyai penguatan daya pada sinyal yang dilewatkan tapis. Sedang tapis aktif terdiri dari komponen-komponen aktif seperti transistor, penguat operasi dan sebagainya selain komponen-komponen pasif [5]. Tapis aktif mempunyai penguatan daya pada sinyal yang dilewatkan tapis. Tapis dapat memisahkan frekuensi sinyal-sinyal yang diinginkan dari frekuensi sinyal-sinyal yang tidak diinginkan. Tanggapan frekuensi dari suatu tapis merupakan grafik perolehan tegangan terhadap frekuensi. Jenis-jenis tapis berdasarkan frekuensi sinyal yang dilewatkan yaitu: low pass, high pass, passband, bandstop dan allpass [6]. Pengatur nada rendah dan nada tinggi menggunakan metode penapisan frekuensi dengan tapis tipe Butterworth orde satu dan pada perancangan ini menggunakan tapis pelewat frekuensi rendah (low pass filter) dan tapis pelewat frekuensi tinggi (high pass filter). Tapis-tapis tersebut ditentukan titik frekuensi penggal sesuai dengan frekuensi nada yang dikehendaki. Hasil rancangan akan dilakukan pengukuran dengan Simulator Circuit Maker.

\subsection{Tapis Pelewat Frekuensi Rendah}

Gambar 2a menunjukkan tanggapan frekuensi ideal dari tapis pelewat frekuensi rendah. Tapis pelewat frekuensi rendah melewatkan semua frekuensi dari nol sampai 
frekuensi penggal dan memblok semua frekuensi di atas frekuensi penggal. Frekuensi antara nol dan frekuensi penggal disebut passband dan frekuensi di atas frekuensi penggal disebut stopband. Tapis pelewat frekuensi rendah mempunyai pergeseran fase nol untuk semua frekuensi pada passband. Tapis pelewat frekuensi rendah ideal mempunyai atenuasi nol pada passband dan tak terhingga pada stopband. Gambar $2 \mathrm{~b}$ menunjukkan tanggapan frekuensi yang nyata dari tapis pelewat frekuensi rendah.

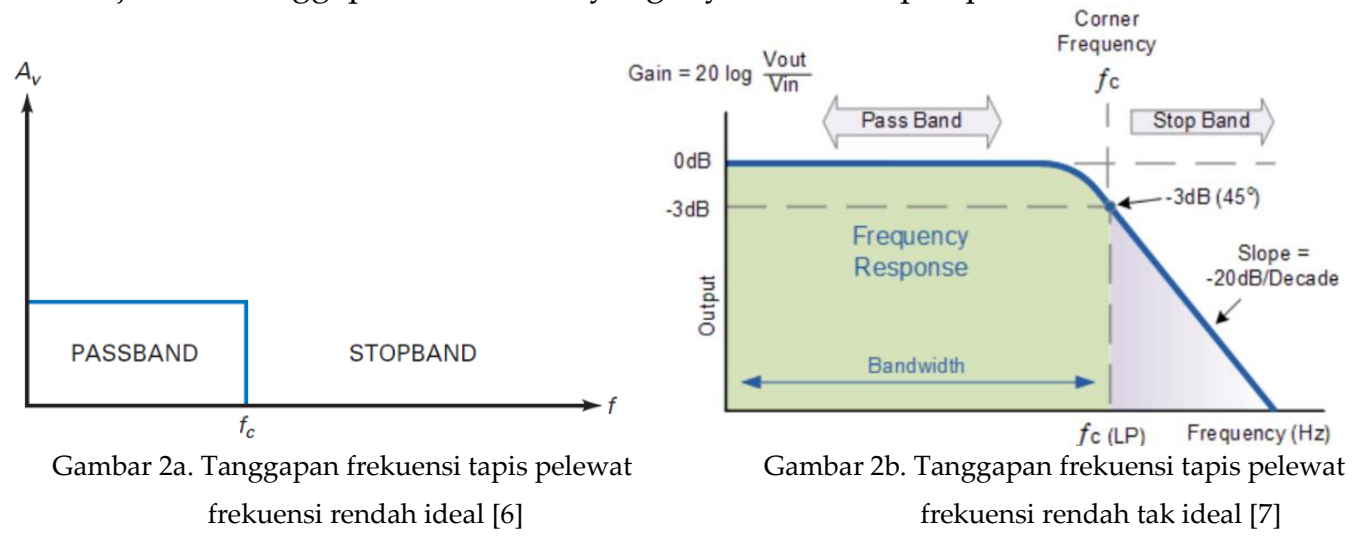

\subsection{Tapis Pelewat Frekuensi Tinggi}

Gambar 3a menunjukkan tanggapan frekuensi ideal dari tapis pelewat frekuensi tinggi. Tapis pelewat frekuensi tinggi memblok semua frekuensi dari nol sampai frekuensi penggal dan melewatkan semua frekuensi di atas frekuensi penggal. Frekuensi antara nol dan frekuensi penggal disebut stopband dan frekuensi di atas frekuensi penggal disebut passband. Gambar 3b menunjukkan tanggapan frekuensi yang nyata dari tapis pelewat frekuensi tinggi.

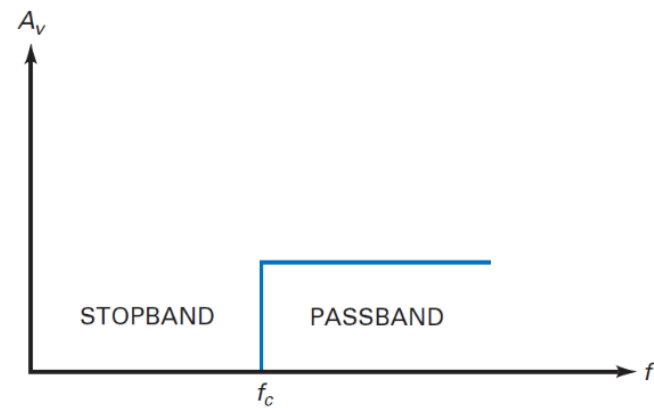

Gambar 3a. Tanggapan frekuensi tapis pelewat frekuensi tinggi ideal [6]

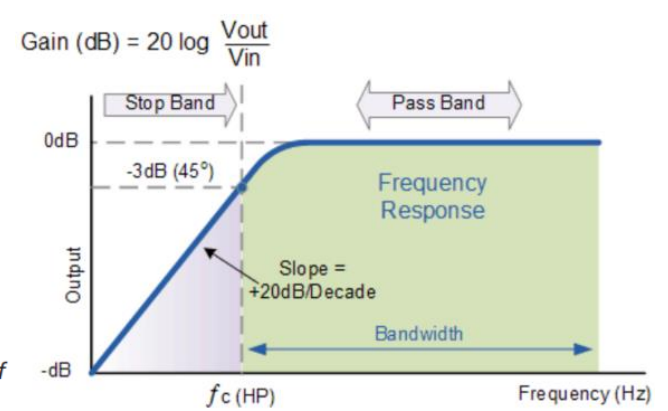

Gambar 3b. Tanggapan frekuensi tapis pelewat frekuensi tinggi tak ideal [8]

\subsection{Tapis Tipe Butterworth}

Penaksiran Butterworth kadang-kadang disebut penaksiran datar secara maksimal karena atenuasi passband adalah nol yang melewatkan sebagian besar passband dan menurunkan perolehan (gain) secara berangsur pada tepi passband. Di atas tepi passband, tanggapan akan menurun pada nilai kira-kira $20 \mathrm{~dB}$ tiap dekade untuk orde satu. Gambar 4 berikut menunjukkan tanggapan frekuensi tapis pelewat frekuensi rendah tipe Butterworth orde 1 dengan frekuensi penggal $1 \mathrm{kHz}$. Tipe-tipe tapis selain Butterworth adalah: Chebyshev, Bessel dan Eliptik. Pada perancangan ini hanya dipergunakan tapis tipe Butterworth. 


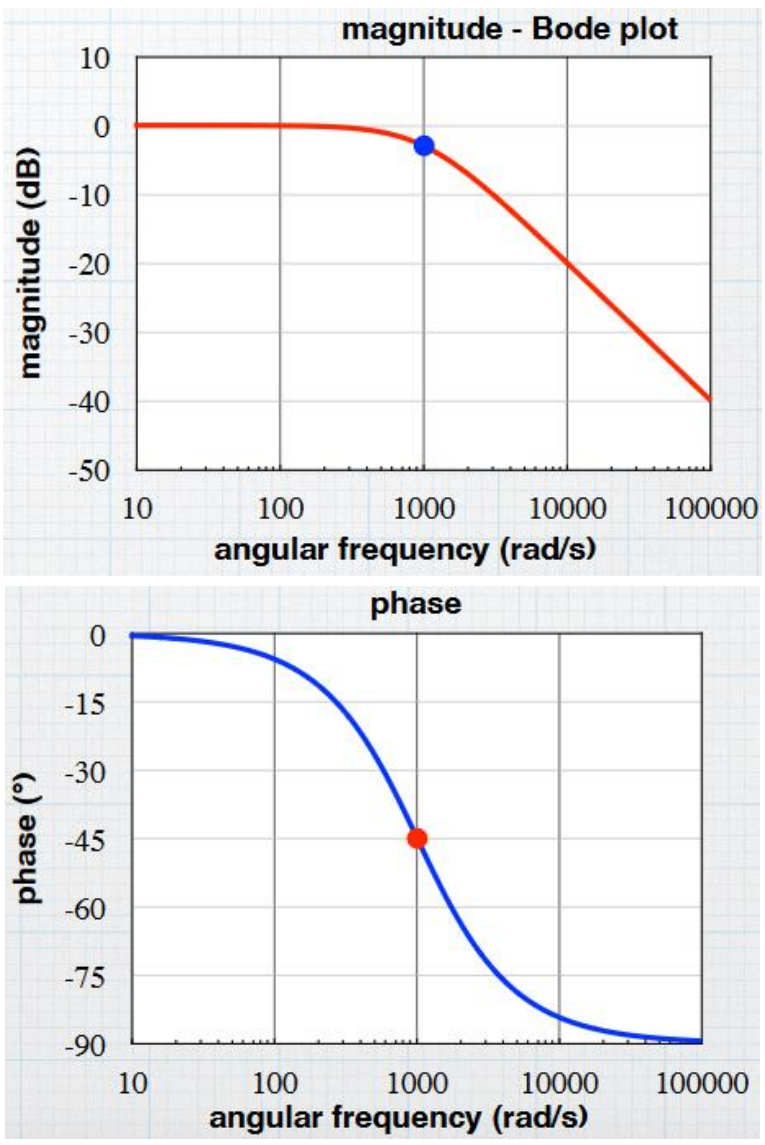

Gambar 4. Tanggapan frekuensi tapis pelewat frekuensi rendah Butterworth orde 1 [9]

\subsection{Kutub (Pole) dan Nol (Zero)}

Fungsi alih domain-s selalu merupakan fungsi polinomial rasional dari bentuk [10]:

$$
T(s)=\frac{\left(a_{m} \cdot s^{m}+a_{m-1} s^{m-1}+\ldots+a_{0}\right)}{\left(s^{n}+b_{n-1} \cdot s^{n-1}+\ldots+b_{0}\right)}
$$

Pada persamaan 1 polinomial dalam pembilang dan penyebut difaktorkan untuk memperoleh kutub dan nol, ini adalah nilai s yang membuat pembilang atau penyebutnya nol. Jika kita menulis nol sebagai $z 1, z 2, z 3 \ldots$ dst., dan dengan cara yang sama menulis kutub sebagai $p 1, p 2, p 3 \ldots$, maka $T(s)$ dapat ditulis dalam bentuk faktor sebagai [10]:

$$
T(s)=\frac{a^{m}\left(s-Z_{1}\right)\left(s-Z_{2}\right) \ldots\left(s-Z_{m}\right)}{\left(s-P_{1}\right)\left(s-P_{2}\right) \ldots\left(s-P_{n}\right)}
$$

Lokasi kutub dan nol bisa nyata atau kompleks. Jika akar-akarnya real disebut kutub sederhana atau nol sederhana. Ketika akarnya kompleks, mereka selalu muncul berpasangan yaitu dalam bentuk konjugasi kompleks satu sama lain. Berikut kutub sederhana dengan mempertimbangkan fungsi alih dari rangkaian orde pertama dengan kutub sederhana di $s=-1$. Respons frekuensi keadaan tunak ditentukan dengan membiarkan $s \rightarrow \mathrm{j} \omega[11]$.

$$
H(s)=\frac{1}{s+1} \text { atau } H(j \omega)=\frac{1}{j \omega+1}
$$

Besarnya fungsi alih diberikan oleh

$$
|H(j \omega)|=\left[\omega^{2}+1\right]^{-1 / 2}
$$


Fungsi ini diplot pada Gambar 5 untuk frekuensi dua orde di atas dan di bawah $\omega=1$ yang mempunyai tanggapan sangat berbeda di kedua sisi tersebut. Perilaku asimtotik untuk $\omega<<<1$ dan $\omega \gg>>1$ dapat dicari dari persamaan (5) sebagai:

$$
|H(j \omega)|_{d B}=\begin{array}{cc}
0 d B & \omega \ll 1 \\
-20 \log \omega d B & \omega \gg 1
\end{array}
$$

Asimtot ini berupa garis-garis lurus pada grafik $\mathrm{dB}$ vs $\log \omega$. Untuk $\omega \ll<1$ fungsinya adalah konstan, yaitu $|\mathrm{H}|=1$ atau $0 \mathrm{~dB}$. Pada bagian ekstrim lainnya di mana $\omega \gg>1$, fungsi alih berkurang sebagai $-20 \log \omega$ dalam $\mathrm{dB}$, pada skala log frekuensi ini berupa garis lurus dengan kemiringan $-20 \mathrm{~dB} /$ dekade, yaitu fungsi alih berkurang $20 \mathrm{~dB}$ untuk setiap kelipatan sepuluh dari kenaikan frekuensi. Kemiringan ini setara dengan -6 dB/oktaf [12]. Dua garis lurus asimtot bertemu di titik frekuensi yang sesuai dengan letak kutub. Titik ini juga disebut dengan titik frekuensi penggal. Pada titik ini fungsi alih memiliki besar:

$$
|H(j 1)|=\frac{1}{\sqrt{2}} \text { atau }-3 d B
$$

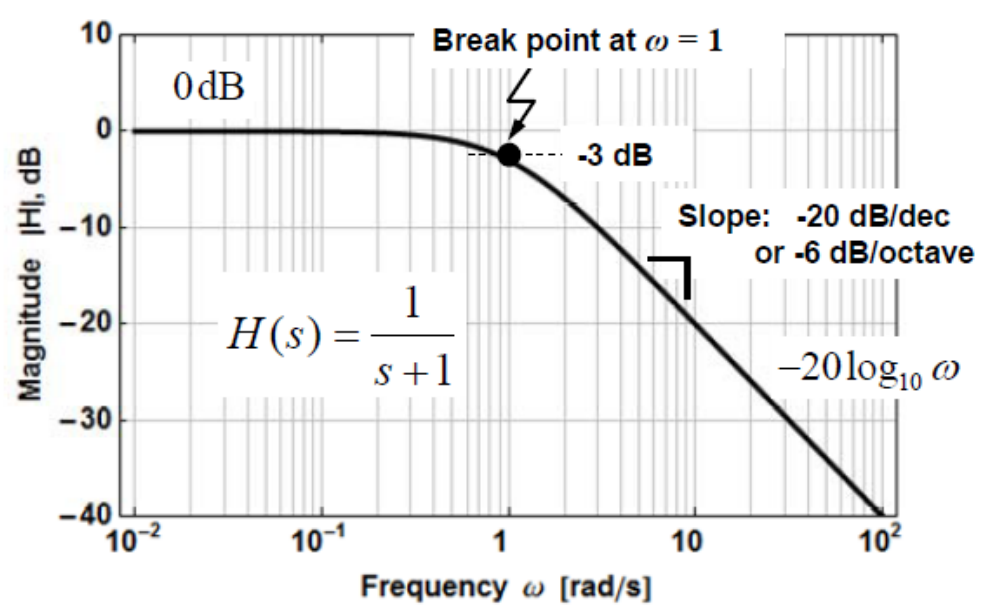

Gambar 5. Tanggapan frekuensi kutub (pole) sederhana pada s $=-1$ [11]

Fungsi alih nol sederhana berperilaku serupa, seperti ditunjukkan pada Gambar 6, kecuali bahwa fungsi alih mulai naik di titik frekuensi penggal dan bukannya turun. Laju perubahannya adalah sama $20 \mathrm{~dB}$ per dekade di atas titik frekuensi penggal.

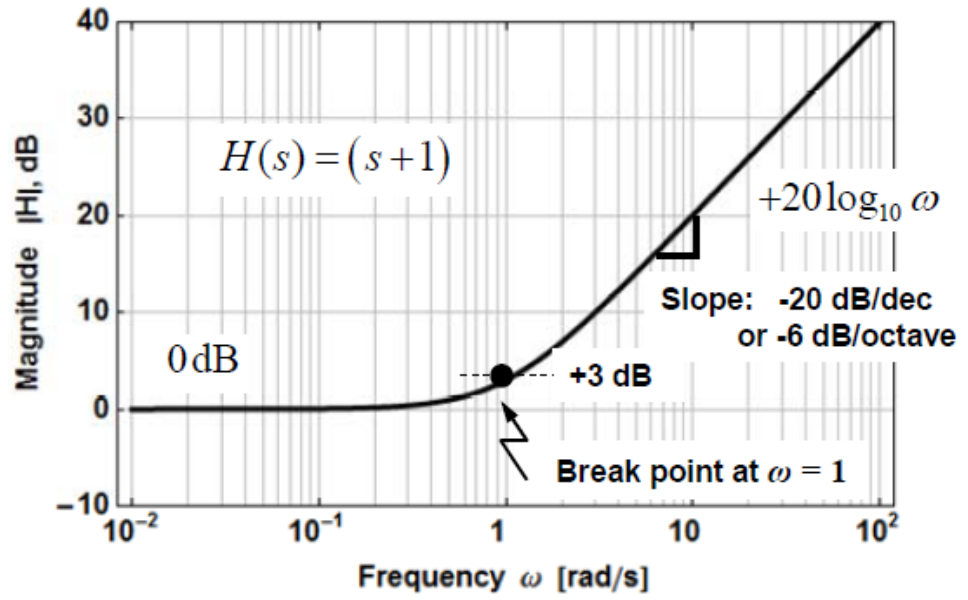

Gambar 6. Tanggapan frekuensi nol (zero) sederhana pada s $=-1$ [11] 


\section{Perhitungan Nilai Komponen}

Perhitungan nilai komponen pengatur nada rendah dan tinggi dilakukan agar hasilnya sesuai dengan spesifikasi yang diharapkan. Perhitungan terpenting dilakukan pada keadaan atau posisi ekstrim yaitu:

- saat pengatur nada rendah (bass) pada keadaan mempunyai penguatan maksimum yang disebut bass-boost dan saat pengatur nada rendah (bass) pada keadaan mempunyai pelemahan maksimum yang disebut bass-cut.

- saat pengatur nada tinggi (treble) pada keadaan mempunyai penguatan maksimum yang disebut treble-boost dan saat pengatur nada tinggi (treble) pada keadaan mempunyai pelemahan maksimum yang disebut treble-cut.

\subsection{Bass Boost}

Untuk frekuensi rendah kapasitor pengatur nada pasif pada Gambar 1, C3 dan C4 akan bersifat hubung buka atau mempunyai nilai impedansi yang sangat besar. Nilai reaktansi kapasitif berbanding terbalik dengan frekuensi [13]. Pada keadaan penguatan nada rendah maksimum maka kapasitor $\mathrm{C} 1$ akan hubung singkat karena potensiometer R2 pada posisi teratas. Untai setara bass boost ditunjukkan pada Gambar 7.

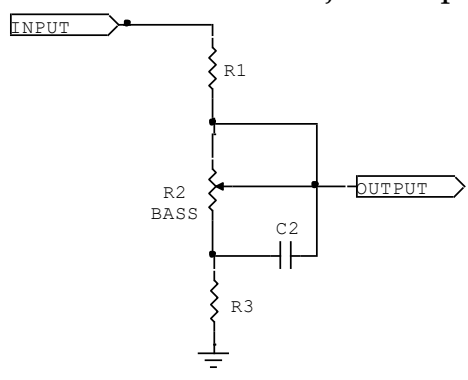

Gambar 7. Bass boost

$$
\begin{aligned}
& V o=V i \frac{R 3+R 2 / / X c 2}{R 1+R 3+R 2 / / X c 2} \\
& V o=V i \frac{R 3+\frac{R 2}{s R 2 C 2+1}}{R 1+R 3+\frac{R 2}{s R 2 C 2+1}}
\end{aligned}
$$

Persamaan tersebut mempunyai nol (zero):

$$
\begin{aligned}
& s 01=\frac{1+R 2 / R 3}{R 2 C 2} \\
& s p 2=\frac{1+\frac{R 2}{R 1+R 3}}{R 2 C 2}
\end{aligned}
$$

Notasi s mengandung besaran frekuensi yaitu $s=\mathrm{j} \omega$ dimana $\omega=2 \pi f[12]$.

Penguatan untuk bass-boost frekuensi tinggi adalah:

$$
A v 1=\frac{R 3}{R 1+R 3}
$$

Penguatan untuk bass-boost frekuensi rendah adalah:

$$
A v 2=\frac{R 2+R 3}{R 1+R 2+R 3}
$$

\subsection{Bass Cut}

Untuk frekuensi rendah kapasitor pada pengatur nada tinggi C3 dan C4 akan bersifat hubung buka atau mempunyai nilai impedansi yang sangat besar. Pada keadaan 
pelemahan nada rendah maksimum maka kapasitor C2 akan hubung singkat karena potensiometer R2 pada posisi terbawah.

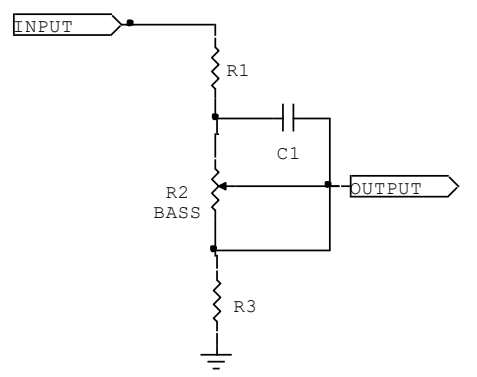

Gambar 8. Bass cut

$$
\begin{gathered}
V o=V i \frac{R 3}{R 1+R 3+R 2 / / X c 1} \\
V o=V i \frac{R 3}{R 1+R 3} \cdot \frac{s R 2 C 1+1}{s R 2 C 1+1+\frac{R 2}{R 1+R 3}}
\end{gathered}
$$

Persamaan tersebut mempunyai nol (zero):

$$
s 03=-\frac{1}{R 2 C 1}
$$

dan kutub (pole):

$$
s p 4=-\frac{1+\frac{R 2}{R 1+R 3}}{R 2 C 1}
$$

Penguatan untuk bass-cut frekuensi tinggi adalah:

$$
A v 3=\frac{R 3}{R 1+R 3}
$$

Penguatan untuk bass-cut frekuensi rendah adalah:

$$
A v 4=\frac{R 3}{R 1+R 2+R 3}
$$

Ratio pada frekuensi rendah dari pengaturan nada rendah:

$$
\frac{A v 2}{A v 4}=1+\frac{R 2}{R 3}
$$

Untuk rentang pengaturan $40 \mathrm{~dB}$, maka:

$$
1+\frac{R 2}{R 3}=100
$$

sehingga diperoleh:

$$
R 2=99 R 3 \approx 100 R 3
$$

Rasio penguatan tegangan untuk frekuensi rendah dan tinggi saat penguatan nada rendah maksimum (bass-boost) adalah:

$$
\frac{A v 2}{A v 1}=\frac{R 1+R 3}{R 3} \cdot \frac{R 2+R 3}{R 1+R 2+R 3}
$$

Dengan memasukkan persamaan (21) ke persamaan (22), maka diperoleh

$$
\frac{A v 2}{A v 1}=\frac{100(R 1+R 3)}{R 1+100 R 3}
$$

Pada penguatan nada rendah (bass-boost) $20 \mathrm{~dB}$ :

$$
\begin{gathered}
\frac{A v 2}{A v 1}=\frac{100(R 1+R 3)}{R 1+100 R 3}=10 \\
R 1=10 R 3
\end{gathered}
$$


Dengan menggunakan persamaan (17), (18), (21) dan (24) pada pelemahan nada rendah (bass-cut) $20 \mathrm{~dB}$ :

$$
\frac{A v 3}{A v 4}=\frac{R 3}{R 1+R 3} \cdot \frac{R 1+R 2+R 3}{R 3}
$$

Akan diperoleh Av3/Av4 $=10$

Artinya, rasio penguatan frekuensi tinggi dan frekuensi rendah pada pelemahan nada rendah (bass-cut) juga $20 \mathrm{~dB}$. Untuk memperoleh tanggapan frekuensi yang simetri kita harus memilih $\mathrm{s} 01=\mathrm{sp} 4$.

Dari persamaan (9), (16), (21) dan (25) diperoleh:

$$
C 2=10 C 1
$$

\subsection{Treble Boost}

Untuk frekuensi tinggi kapasitor pada pengatur nada rendah $\mathrm{C} 1$ dan $\mathrm{C} 2$ akan bersifat hubung singkat atau mempunyai nilai impedansi yang sangat kecil. Pada keadaan penguatan nada tinggi maksimum maka potensiometer R6 pada posisi teratas .

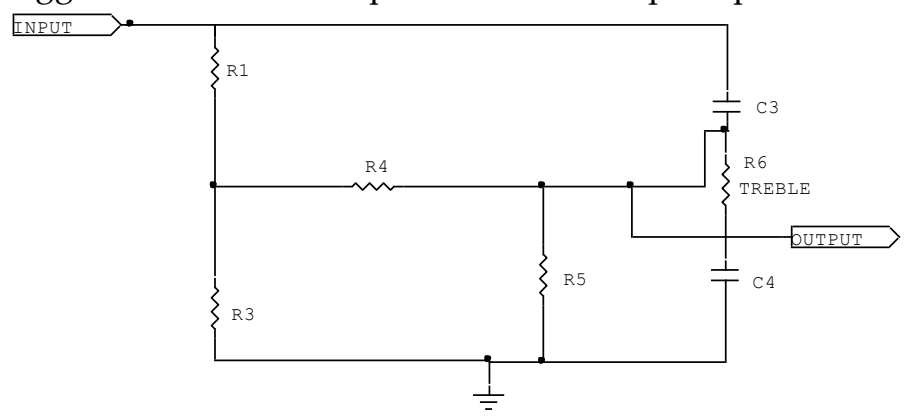

Gambar 9. Treble boost

Untuk melakukan perhitungan perlu dicari untai setara Thevenin untuk Vin, R1 dan R3. Untai setara thevenin terdiri dari satu sumber tegangan thevenin dan satu hambatan thevenin dimana besarnya tegangan thevenin adalah sama dengan tegangan terminal keluaran saat hubung buka dan besarnya hambatan thevenin adalah sama dengan besarnya hambatan pada terminal keluaran tanpa beban [14]. Dalam Gambar 9, hambatan Thevenin Rth = R1//R2 dan sumber tegangan Thevenin Vth diberikan oleh:

$$
V t h=V i \frac{R 3}{R 1+R 3}
$$

Berdasar persamaan (25) diperoleh:

$$
V t h=\frac{V i}{11}
$$
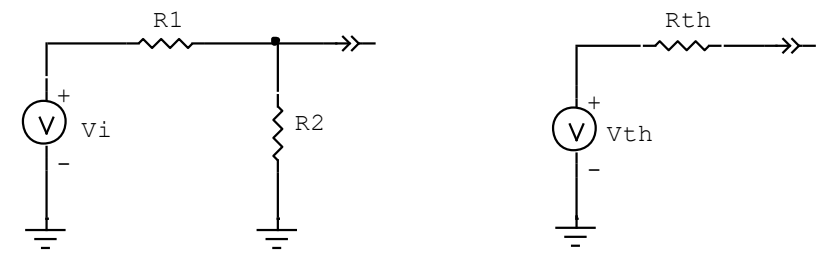

Gambar 10. Untai setara thevenin

Dengan asumsi arus yang melalui resistor R6 jauh lebih kecil daripada yang mengalir melalui R4, maka

$$
\frac{V t h-V o}{R t h+R 4}=(V o-V i) s C 3
$$


Jika R5>>R4.

Substitusi persamaan (29) untuk $V_{1}$ :

$$
\frac{\frac{V i}{11}-V o}{R t h+R 4}=(V o-V i) s C 3
$$

Berdasarkan persamaan tersebut akan diperoleh:

$$
\frac{\mathrm{Vo}}{\mathrm{Vi}}=\frac{\frac{1}{11}+\mathrm{sC} 3(\mathrm{Rth}+\mathrm{R} 4)}{1+\mathrm{sC} 3(\mathrm{Rth}+\mathrm{R} 4)}
$$

Penguatan untuk treble-boost frekuensi rendah adalah:

$$
A v 5=\frac{V o}{V i}=\frac{1}{11}
$$

Penguatan tersebut dalam dB setara dengan $20 \log (1 / 11)=-20,8 \mathrm{~dB}$.

Penguatan untuk treble-boost frekuensi tinggi adalah:

$$
A v 6=\frac{V o}{V i}=1
$$

Penguatan Av6 tersebut dalam dB setara dengan 20log(1) = 0 dB. Persamaan (30) memiliki nol (zero) yang diberikan oleh:

$$
\begin{gathered}
s 05=-\frac{1}{11(\text { Rth }+R 4) C 3} \\
s p 6=-\frac{1}{(\text { Rth }+R 4) C 3}
\end{gathered}
$$

\subsection{Treble Cut}

Untuk frekuensi tinggi kapasitor pada pengatur nada rendah C1 dan C2 akan bersifat hubung singkat atau mempunyai nilai impedansi yang sangat kecil. Pada keadaan penguatan nada rendah minimum maka potensiometer R6 pada posisi terbawah .

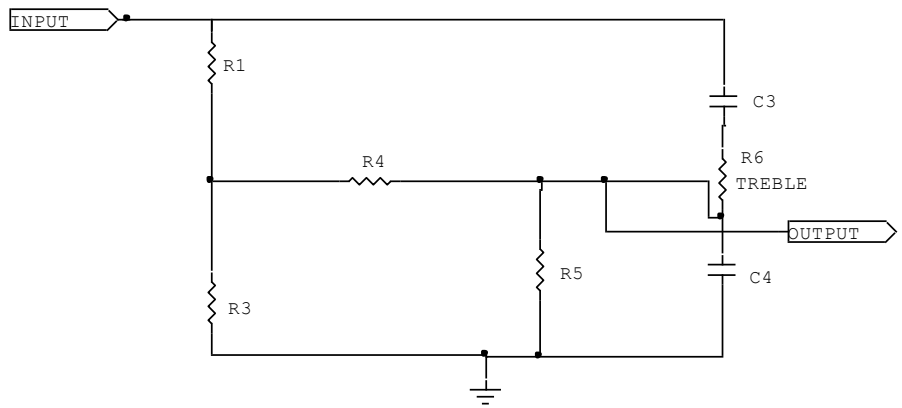

Gambar 11. Treble cut

$$
\begin{gathered}
\frac{V t h-V o}{R t h+R 4}=s C 4 V o \\
\frac{V o}{V t h}=\frac{1}{1+s(R t h+R 4) C 4}
\end{gathered}
$$

Dengan memasukkan persamaan (29) ke persamaan (38) maka:

$$
\frac{V o}{V i}=\frac{1}{11[1+s(R t h+R 4) C 4]}
$$

Penguatan untuk treble-cut frekuensi rendah adalah:

$$
A v 7=\frac{V o}{V i}=\frac{1}{11}
$$

Penguatan tersebut dalam dB setara dengan $20 \log (1 / 11)=-20,8 \mathrm{~dB}$.

Penguatan untuk treble-cut frekuensi tinggi adalah: 


$$
A v 8=\frac{V o}{V i} \approx 0
$$

Persamaan (37) mempunyai kutub (pole) yang diberikan sebagai:

$$
s p 7=-\frac{1}{(R t h+R 4) C 4}
$$

Agar diperoleh tanggapan frekuensi yang simetri harus harus dipilih sp7 = s05:

Diperoleh:

$$
\frac{1}{(\mathrm{Rth}+\mathrm{R} 4) \mathrm{C} 4}=\frac{1}{11(\mathrm{Rth}+\mathrm{R} 4) \mathrm{C} 3}
$$

$$
C 4=11 C 3
$$

Perhitungan nilai R6 dengan asumsi bahwa arus yang melalui R6 sangat kecil dibandingkan dengan yang mengalir melalui R4 (IR6 « IR4).

Besarnya arus yang mengalir melalui R4:

$$
I R 4=\frac{\frac{V i}{11}-V o}{R \operatorname{th}+R 4}
$$

Besarnya arus yang mengakir melalui R6:

$$
I R 6=\frac{V i-V o}{R 6+\frac{1}{s C 3}}
$$

Karena IR4 $<<$ IR4 maka dari persamaan (42) dan (43) untuk frekuensi cukup tinggi diperoleh:

$$
\begin{aligned}
& \frac{\frac{V i}{11}-V o}{V i-V o} \gg \frac{R t h+R 4}{R 6} \\
& \frac{\frac{1}{11}-\frac{V o}{V i}}{1-\frac{V o}{V i}} \gg \frac{R t h+R 4}{R 6}
\end{aligned}
$$

Berdasar persamaan (39) di mana $V \mathrm{o} / V \mathrm{i} \approx 0$, maka diperoleh:

$$
R 6 \gg 11(R t h+R 4)
$$

Letak kutub (pole) dan nol (zero) digambarkan secara idealnya pada gambar berikut:

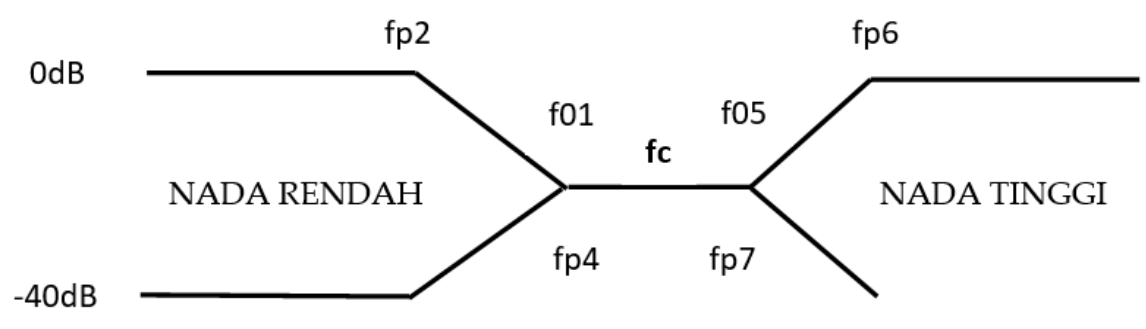

f03

Gambar 12. Letak kutub (pole) dan nol (zero)

Frekuensi pusat $f c$ adalah rerata geometri dari dua buah frekuensi penggal f01 dan f05 dan hubungannya adalah sebagai:

\subsection{Nilai Komponen}

$$
f c=\sqrt{f 01 . f 05}
$$

Pertama kali ditentukan nilai peubah $\mathrm{R} 2=100 \mathrm{~K}$. Sesuai persamaan (21) dan (25) diperoleh nilai $\mathrm{R} 1=10 \mathrm{~K}$ dan $\mathrm{R} 3=1 \mathrm{~K}$. Dengan menetapkan frekuensi tengah $\mathrm{fc}=1 \mathrm{kHz}$, maka nilai f01, fp4, f05, fp7 dipilih mendekati frekuensi tengah. Dengan menggunakan 
persamaan (9), (15) dan (16) diperoleh nilai C2 = $200 \mathrm{nF}$ dan nilai $\mathrm{f} 01=\mathrm{fp} 4=795,7 \mathrm{~Hz}$ dan $\mathrm{fp} 2=79,6 \mathrm{~Hz}$. Sesuai persamaan (27) diperoleh nilai C1 = 20nF. R4 ditetapkan sebesar 10 K. Dengan menggunakan persamaan (35), (36) dan (42) diperoleh nilai C3 = $1 \mathrm{nF}$ dan nilai $\mathrm{f} 05=\mathrm{fp} 7=1.326,3 \mathrm{~Hz}$ dan fp6 $=14.589,3 \mathrm{~Hz}$. Sesuai persamaan (43) diperoleh nilai C4 = 11 $\mathrm{nF}$. Dengan persamaan (48) diperoleh nilai R6 = $100 \mathrm{~K}$ dan dengan persamaan (49) diperoleh nilai frekuensi pusat $\mathrm{fc}=1027,4 \mathrm{~Hz}$.

\section{Hasil Pengukuran}

Pada pengukuran untai pengatur nada rendah dan nada tinggi dipergunakan nilai komponen-komponen sesuai hasil perhitungan. Keluaran untai ini umumnya dihubungkan dengan untai penguat yang mempunyai impedansi masukan tinggi seperti halnya penguat operasi mempunyai hambatan masukan lebih besar dari $1 \mathrm{M}$ ohm [14]. Pada pengukuran ini keluaran untai diberi beban R5 $=100 \mathrm{~K}$. Pengukuran dilakukan dengan posisi pengatur nada rendah dan nada tinggi bervariasi pada keadaan netral, maksimum dan minimum dan hasil pengukuran ditunjukkan pada Gambar 13 sampai dengan Gambar 19.

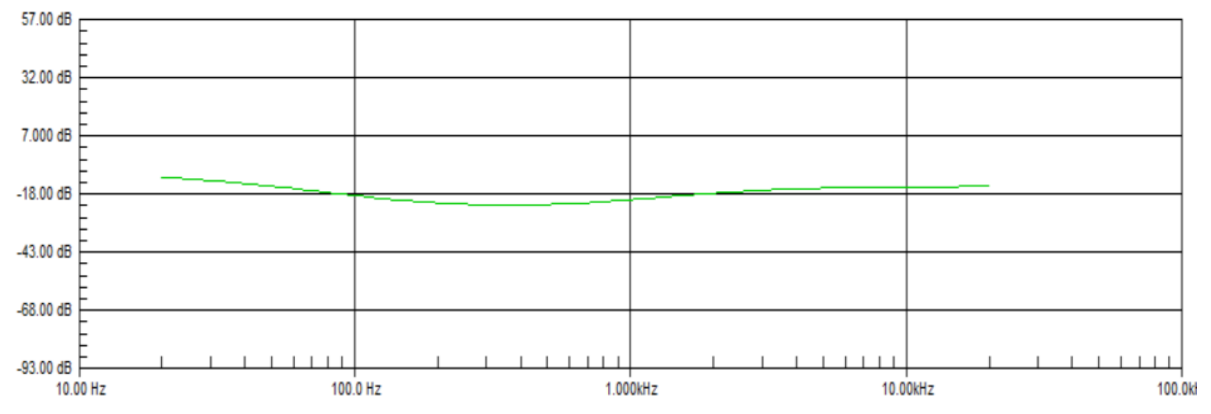

Gambar 13. Posisi pengatur nada rendah dan pengatur nada tinggi netral

Acuan rata-rata pada frekuensi $20 \mathrm{kHz}=-20 \mathrm{~dB}$.

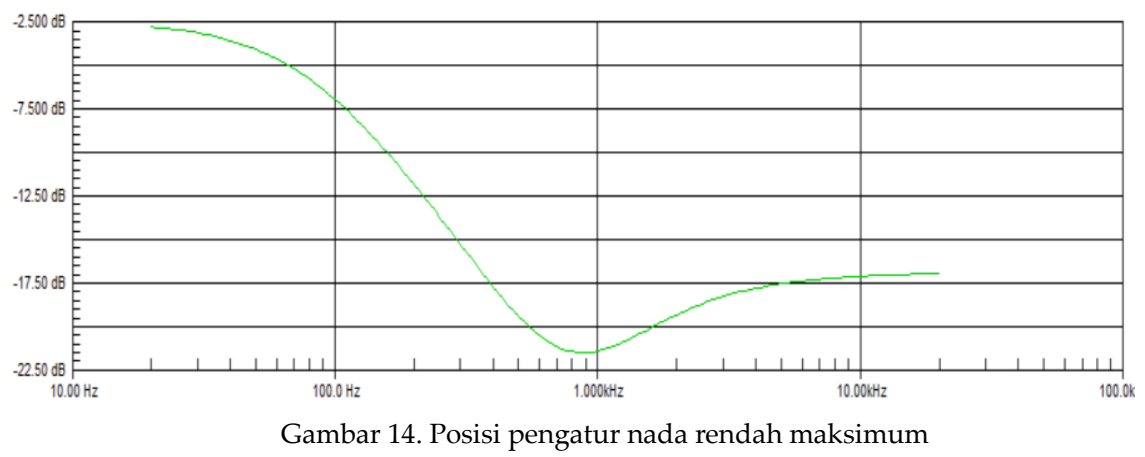

Aras maksimum $=-2,5 \mathrm{~dB}$ dan aras pada frekuensi $1 \mathrm{kHz}=-21,4 \mathrm{~dB}$ 


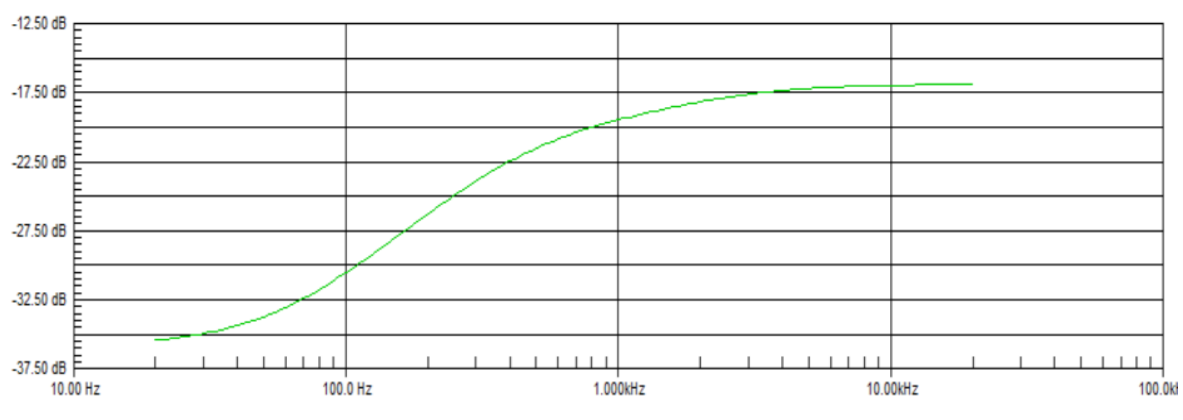

Gambar 15. Posisi pengatur nada rendah minimum

Arus minimum $=-35,4 \mathrm{~dB}$ dan aras pada frekuensi $1 \mathrm{kHz}=-19,4 \mathrm{~dB}$.

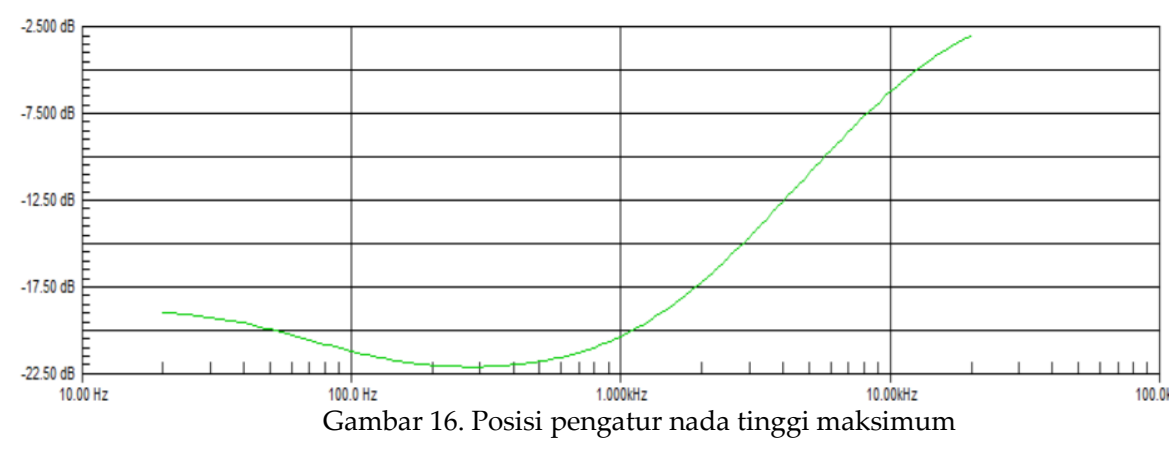

Aras maksimum $=-3 \mathrm{~dB}$ dan aras pada frekuensi $1 \mathrm{kHz}=-20,4 \mathrm{~dB}$.

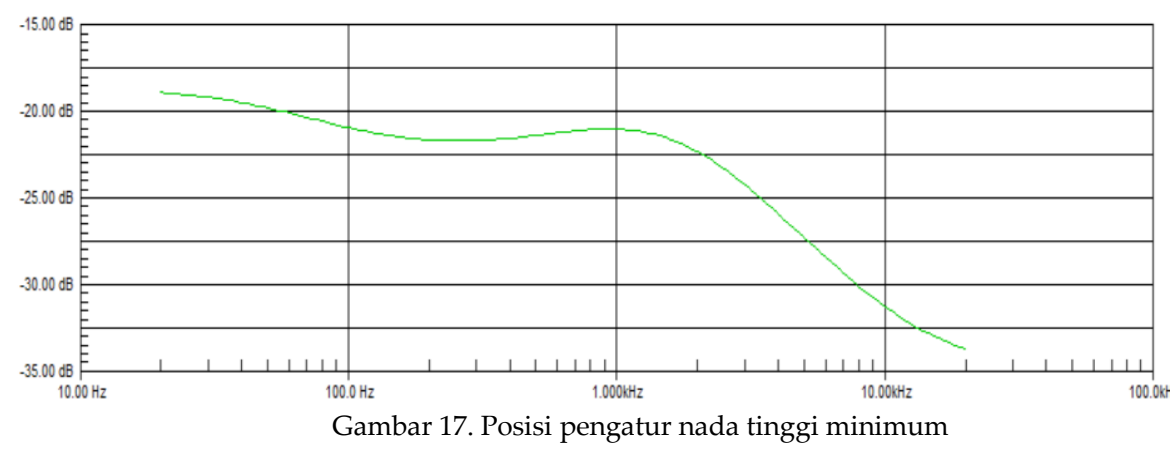

Aras minimum $=-33,7 \mathrm{~dB}$ dan aras pada frekuensi $1 \mathrm{kHz}=-21 \mathrm{~dB}$.

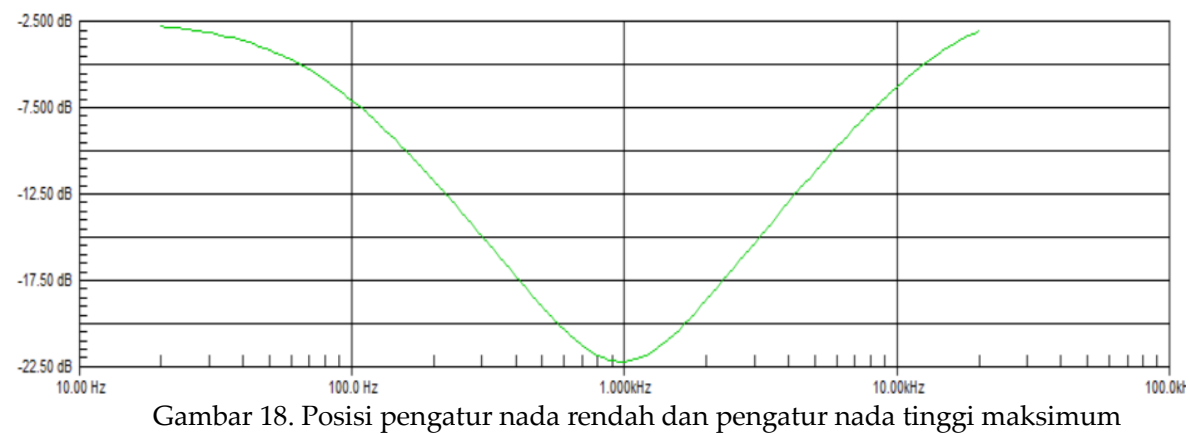

Aras maksimum $=-2,6 \mathrm{~dB}$ dan aras pada frekuensi $1 \mathrm{kHz}=-22 \mathrm{~dB}$. 


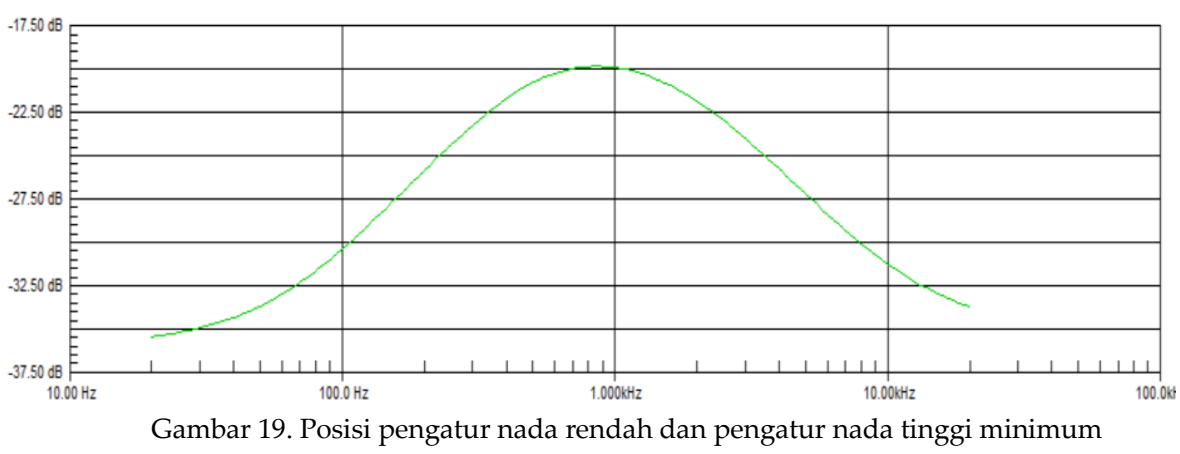

Aras minimum $=-36 \mathrm{~dB} \& 33,5 \mathrm{~dB}$ dan aras pada frekuensi $1 \mathrm{kHz}=-19 \mathrm{~dB}$.

\section{Kesimpulan}

Pengaturan nada rendah maksimum belum mencapai $+20 \mathrm{~dB}$ karena pada hasil pengukuran $=+18,9 \mathrm{~dB}$ dan pengaturan nada rendah minimum belum mencapai $-20 \mathrm{~dB}$ karena pada hasil pengukuran $=-16 \mathrm{~dB}$. Pengaturan nada tinggi maksimum belum mencapai $+20 \mathrm{~dB}$ karena pada hasil pengukuran $=+17,4 \mathrm{~dB}$ dan pengaturan nada rendah minimum belum mencapai $-20 \mathrm{~dB}$ karena pada hasil pengukuran $=-12,7 \mathrm{~dB}$. Pengaturan nada rendah dan nada tinggi maksimum menunjukkan frekuensi penggal nada rendah mendekati $75 \mathrm{~Hz}$ dan frekuensi penggal nada tinggi mendekati $11,6 \mathrm{kHz}$ serta frekuensi pusat mendekati $1 \mathrm{kHz}$. Hasil pengukuran tersebut menyimpang 5,8\% dari hasil perhitungan frekuensi penggal bawah $=79,6 \mathrm{~Hz}$ dan menyimpang 20,5\% dari hasil perhitungan frekuensi penggal atas $=14.589,3 \mathrm{~Hz}$ serta menyimpang $2,7 \%$ dari hasil perhitungan frekuensi pusat $=1027,4 \mathrm{~Hz}$.

\section{Daftar Pustaka}

[1] Pengertian Komponen Elektronika Aktif dan Komponen Elektronika Pasif [Online], https://teknikelektronika.com/pengertian-komponen-elektronika-aktif-komponenelektronika-pasif/, diakses tanggal 1 Juni 2021.

[2] Amplifier Control [Online], https://learnaboutelectronics.org/Amplifiers/amplifiers42.php diakses tanggal 19 Januari 2021.

[3] Self, Douglas," ", Focal Press, 1st edition, h. 259-268, 2010.

[4] J. Denton Daile, "Electronics for Guitarists", Springer, ISBN 9781441995353. h. 47-49, 2011.

[5] Electronics Component [Online], https://en.wikipedia.org/wiki/Electronic component\#Classification, diakses pada 5 Juni 2021.

[6] Albert Malvino, David J. Bates, "Electronic principles", McGraw-Hill Education, 8th edition, h. 790-791, 2016.

[7] Passive Low Pass Filter [Online], https://www.electronicstutorials.ws/filter/filter 2.html, diakses pada 10 Juni 2021.

[8] Passive High Pass Filter [Online], https://www.electronicstutorials.ws/filter/filter 3.html, diakses pada 10 Juni 2021

[9] EE 230 Electronic Circuits \& Systems Spring 2020, "First Order Filters" [Online], http://tuttle.merc.iastate.edu/ee230/topics/filters/first order.pdf, diakses pada 23 September 2021. 
[10] Adel S. Sedra and Kenneth C. Smith, "Microelectronic circuits", Oxford University Press, 7th edition, 2015.

[11] Bob York, "Frequency Response and Bode Plots" [Online], https://web.njit.edu/ revkov/classes_files/ECE232/Handouts/Frequency\%20Response.pdf, diakses pada 10 Agustus 2021.

[12] William H. Hayt, Jr., Jack E. Kemmerly and Steven M. Durbin, "Engineering Circuit Analysis, , McGraw-Hill Companies, Inc., $8^{\text {th }}$ edition, h. 541 \& 650, 2012.

[13] Allan H. Robbins and Wilhelm C. Miller ,"Circuit Analysis: Theory and Practice", Delmar Cengage Learning, 5th edition, h. 554-558, 2012

[14] James A. Svoboda and Richard C. Dorf, "Introduction to Electric Circuits", John Wiley \& Sons, Inc., 9th edition, 2014. 